\title{
Os primeiros anos dos Arquivos Médicos do ABC
}

Szulim Ber Zyngier ${ }^{1}$

\section{$\mathrm{T}$} enho em mãos o volume 1, fascículo único de 1978 dos Arquivos Médicos do ABC (AMABC). Ao folheá-lo vão surgindo imagens dos alunos e professores que levaram adiante, enfrentando grandes dificuldades, a idéia de dotar a Faculdade de Medicina do ABC de uma publicação que, como está no Editorial “difundisse a contribuição científica desta Unidade como também oferecer as páginas da Revista a todos os que trabalham na medicina e ciências afins, através das seções de artigos originais, atualização, revisão e História da Medicina”.

A maior dificuldade era arcar com os custos da publicação. A Congregação da Faculdade julgou a idéia da revista prematura naquela ocasião. Os alunos que freqüentavam a Disciplina de Farmacologia como monitores, pesquisadores e agregados, encamparam o desafio e se puseram a procurar entre médicos, professores, laboratórios farmacêuticos e clínicos, patrocínio que permitiria a edição do primeiro volume.

Como foram os alunos da Faculdade que providenciaram os meios para o surgimento da Revista resolvemos que esta seria uma publicação do Diretório Acadêmico Nylceo Marques de Castro e o Conselho Editorial ficaria a cargo dos alunos enquanto os professores fariam parte do Conselho Consultivo.

É interessante examinar os nomes dos membros do primeiro Conselho Editorial e do Consultivo. É uma sucessão de indivíduos que se destacaram e ainda se destacam nos campos científico e docente. Vários dos então acadêmicos hoje são Professores da Faculdade.

Neste primeiro número também foram publicados os Resumos dos trabalhos apresentados no III COMUABC (Congresso Médico Universitário do ABC) e a fotografia do encerramento do evento, no momento em que o Prof. Andrew Victor Schally, Prêmio Nobel de Medicina de 1977 recebe uma homenagem do presidente do Congresso, o então acadêmico Décio Brong Mattar.

O passo seguinte era conseguir a indexação do AMABC no Index Latino-Americano. Seguimos nos números publicados todas as exigências do Index e no volume 3 em 1980 já orgulhosamente exibíamos essa qualificação

No ano seguinte, a Associação dos Docentes da FMABC uniu-se ao Diretório na publicação.

Folheando os números seguintes, até o número 10 de 1987 (Edição Comemorativa de 10 anos), verifica-se que a Revista alcançou plenamente os objetivos a que se propôs no Editorial do seu primeiro número.

Em 1988 eu me licenciei da Faculdade e acompanhei esporadicamente a publicação. Ao voltar encontrei os Arquivos (assim como as Faculdades da Fundação e seus Departamentos) vibrantes e em plena expansão. 